\title{
Reinventing tourism at a traditional cultural tourism destination: a case study of Viana do Castelo (Portugal)
}

\author{
Polytechnic Institute of Viana do Castelo, \\ Avenida do Atlântico, \\ 4900-348 Viana do Castelo, Portugal \\ E-mail: cfernandes@estg.ipvc.pt \\ E-mail: susanarachao@hotmail.com \\ *Corresponding author
}

Carlos Fernandes* and Susana Rachão

\begin{abstract}
Because culture's role in tourism is key and usually the primary reason for visiting certain tourist destinations, the development of cultural tourism as a component of cultural economic development is important in that it requires a destination to sell its culture and creativity to the intended market. This paper seeks to explore the attitudes, expectations and motivations of visitors to Viana do Castelo, in Northern Portugal, to determine how the destination can reinvent a tourism product strategy based on its heritage and the emerging trends in the tourism market. A total of 205 usable questionnaires were collected using a convenience sample of visitors. Results of this study indicate that visitors are essentially independent travellers, seeking to explore the natural and cultural heritage of the region. Finally, a series of observations and recommendations are proposed that support a new form of cultural tourism based on the valuation of local know-how and creative skills in the form of creative tourism.
\end{abstract}

Keywords: culture; creativity; experiences; reinventing; tourism planning; Portugal.

Reference to this paper should be made as follows: Fernandes, C. and Rachão, S. (2014) 'Reinventing tourism at a traditional cultural tourism destination: a case study of Viana do Castelo (Portugal)', Int. J. Business and Globalisation, Vol. 12, No. 3, pp.281-296.

Biographical notes: Carlos Fernandes completed his BA at Syracuse University (USA), MA at Rutgers University (USA) and PhD at Bournemouth University (UK). His interests include alternative tourism strategies and tourism destination management. He has conducted research and/or consultancy within various special interest areas including tourism and gastronomy, cultural tourism, religious tourism and pilgrimage and most recently events. He has coordinated research projects with European Union funding and cooperated in UNWTO activities including 'training the trainer' courses in Angola, Mozambique and Zimbabwe. He also cooperates with the Council of Europe for training on alternative tourism as a strategy for regional development.

Susana Rachão completed her BA in Tourism at the Polytechnic Institute of Viana do Castelo, in Portugal. Currently, she is enrolled in the Master degree in Innovative Tourism Development at the same institution where she has conducted research for her dissertation at the Tourism Laboratory. 


\section{Introduction}

Consumer behaviour in tourism has been changing extensively, developing a more segmented, specialised and sophisticated market mainly aiming at unique activities available at the places visited [Robinson and Novelli, 2005 cited in Novelli et al., (2006) p.1141]. Tourists are more flexible, independent and experienced travellers, whose values and lifestyles are different from those of the mass tourism [Poon, (1993), p.114]. In fact, tourists are looking for emotional stimuli, they want to buy feelings and not products and they want to personally experience the immaterial qualities, seeking ambiance, aesthetics and atmosphere... (Opaschowski, 2001). Figure 1 shows ambiance, aesthetics and atmosphere in Viana do Castelo. Furthermore, visitors are seeking genuine experiences rather than staged ones in their quest for 'deeper' and more 'meaningful' experiences by engaging in alternative forms of tourism, which requires greater creativity on the part of the destination (ETC, 2006).

Figure 1 Ambiance, aesthetics and atmosphere in Viana do Castelo (see online version for colours)

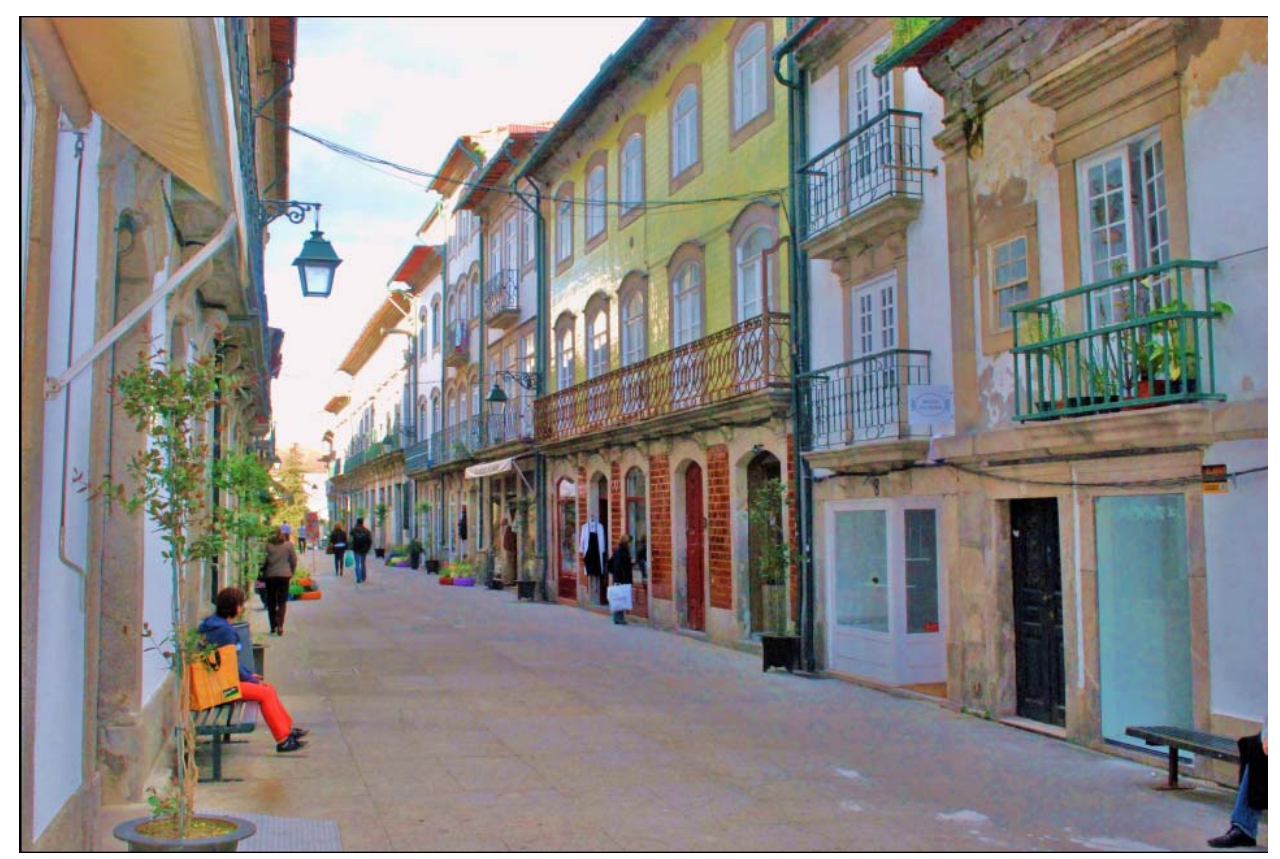

Source: Photograph by Leo Dana

Since tourists are the main consumers of recreational and cultural services as well as a variety of creative products such as crafts and music [UNCTAD, (2010), p.21], and at a time when the loss of diversity and cultural identity uniforms lifestyles $(\ldots)$, the protection of the elements of intangible cultural heritage becomes crucial and represent critical factors for creating new global and competitive scenarios [Cominelli and Greffe, (2012), p.245]. As such, the rise of new tourism consumption patterns where tourists are able to actively choose and participate in their own experience reflects the need to develop alternative tourism approaches with emphasis on creativity applied to tourism. 


\section{Creativity as a tool for the development of tourism}

Despite the difficulty to determine the creativity concept because of its subjectivity, a working definition can be "the goal-oriented individual/team cognitive process that results in a product (idea, solution, service, etc.) that, being judged as novel and appropriate, evokes people's intention to purchase, adopt, use, and appreciate it" [Zeng et al., 2011 cited in Piffer, (2012), p.259]. In fact, creativity is above all about developing new ways of thinking and doing, which explains the close link often made between creativity and innovation and could be applied to tourism through the development of new products or experiences; of new forms of consumption or new tourism spaces [Richards and Wilson, (2007), p.15]. Early links between tourism and creativity were made through analyses of creative activities in destinations which might be of interest to tourists - usually 'cultural tourists' or 'special interest tourists' consuming creative performances or crafts products [Zeppel and Hall, 1992 cit in Richards, (2011), p.1235]. Furthermore, Smith [2005 cited in Rogerson, (2006), p.150] asserts that, the emergence of creative tourism as, in part, a reaction to dissatisfaction with cultural tourism products in recent years. But what is creative tourism?

The first definition of creative tourism was proposed by Richards and Raymond (2000, p.18) during an event in Viana do Castelo and defined as "tourism which offers visitors the opportunity to develop their creative potential through active participation in courses and learning experiences which are characteristic of the holiday destination where they are undertaken". In UNESCO (2006), defined creative tourism as: "travel directed toward an engaged and authentic experience, with participative learning in the arts, heritage, or special character of a place, and it provides a connection with those who reside in this place and create this living culture". So, the essence of creative tourism seems to lie in activities and experiences related to self-realisation and self-expression whereby tourists become co-performers and co-creators as they develop their creative skills [Richards, (2011), p.1237]. Binkhorst (2006, p.2) adds to these definitions in that, experiences can 'touch' people better than products or services and modern consumers want context related, authentic experience concepts and seek a balance between control by the experience stager and self determined activity with its spontaneity, freedom and self expression. Thus, the need to develop unique 'experiences' where tourists are able to co-create their own experience act as a catalyst to develop alternative approaches to tourism planning.

\subsection{Reinventing traditional cultural tourism products towards creative tourism}

Few destinations remain constant and unchanging, and those that do are most likely to be perceived as out of date and unattractive [Butler, 2004 cited in Ioannides, (2006), p.79]. Destinations must adapt, not simply because they must modernise but also because they have to retain and enhance their competitiveness over other localities which leads destinations to constantly reinvent itself to edge out the competition [Ioannides, (2006), p.79]. Poon (1993, pp.293-294) argues that competitive strategies have to be developed based on concepts of flexibility, specialisation and focus to promote the competitive success of tourism. Meethan (1998) goes further and suggests that traditional tourist destinations must restructure or face decline, and that change must occurs at least at three levels: 
1 The tastes of tourists (the consumers of the tourist product) change in different directions. This, of course does not involve 'all' tourists. The majority still seeks the consumption of the '4Ss', but the numbers of those in search of 'something different' is growing.

2 There has been a change in the mode of supply of tourism locations and attractions. Tourists discover new locations and activities, which eventually become fashionable, subsequently organised, and then market their product themselves so as to either meet or to generate new demand. Consequently, they are obliged to enter into a world of intensified competition.

3 There is a change in the providers of both the final product and the intermediate products in an effort to capture new product markets and customers arising from the transformation of the tourist business.

Furthermore, McCole et al. (2004 cited in Hosany and Witham, 2009), assert that it is the ability to create personal experiences for tourists that will provide destinations with a competitive advantage. Product development is a prerequisite for satisfying tourists' needs and changing demands as well as insuring the profitability of the industry (Komppula, 2001). For this reason, knowledge must be created and utilised in the production process with respect to (...) the customer's anticipated interests and tastes [Stamboulis and Skayannis, (2003), p.39] because, there are ever more types of visitors and relative demands, and cities need to provide for new types of cultural uses, suitable for tourists as well as citizens and visitors in general [Sepe and Di Trapani, (2010), p.214].

\subsection{Study context}

Pressures of globalisation and the global economic crisis are leading local authorities to create ways of developing competitive advantage relative to their destinations. With a growing demand of travellers seeking experiences and in order to remain competitive, destinations are focusing on their cultural aspects and consequently in their cultural events to become creative. Viana do Castelo is one such destination.

Viana do Castelo is a municipality on the northern coast of Portugal which historical cultural heritage combined with the natural resources comprise factors of differentiation and attractiveness of the territory and where the trinomial urban-rural-natural is present (ADRIL, 2011). Literature suggests that the main natural and cultural resources present in the municipality of Viana do Castelo were natural landscape, folklore, handicrafts, building heritage, popular festivals, pilgrimages and fairs (ADRIL, 2011; CCDR-N, 2008; DGT, 1999; Sampaio, 1991, 1994). Moreover, Viana do Castelo offers different accommodation facilities, a restaurant sector with gastronomic variety of regional food and gastronomic events throughout the year, as well as a variety of cultural events, nautical, sports and nature-based activities (ADRIL, 2008). These resources and services were instrumental in the Viana Criativa (Creative Viana), a local initiative being branded 'connecting life, apply creativity'. It is supported on a strong and differentiating territorial identity based on creativity - assuming it not only as a distinct feature but also as a transversely attitude observable on people, places and businesses (http://www.vianacriativa.pt/category/noticias/). 
Quem gosta vem, Quem ama fica [Those who like (Viana) come; those who love (Viana) stay] is the newest slogan to brand the municipality of Viana do Castelo. Integrated in the healthy city network, it expresses the quality of life that can be enjoyed by local community and for those who visit it. Viana do Castelo is seen as cultural touring destination and a place of passage which is reflected in the short average duration of stay and the low occupancy and rates which reveal an inability to retain visitors in the region (CCDR-N, 2008).

The creativity dimension could be seen as a potential strategy to be developed by policy makers in order to increase the tourism demand and consequently improve the impact of tourism in the municipality. However, an integrated and coordinated policy for the organisation and promotion of the destination with all stakeholders, throughout the region is needed (ADETURN, 2008), in order to develop tourism products which have the ability to attract visitors from new markets, generate longer stays, increase the expenditure of each visitor, extend the tourism season and attract niche/special interest tourists (Fernandes, 2011b).

\section{Methodology}

A profile of tourists and same-day-visitors in Viana do Castelo is based on consumer research undertaken by the Tourism Laboratory of Polytechnic Institute of Viana do Castelo, Portugal. The aim of the research is to explore the attitudes, expectations and motivations of visitors to Viana do Castelo, in Northern Portugal. The basic objectives of the research are to:

1 analyse the visitor's profiles and origin and their basic motivations

2 analyse visitor's travel behaviour during their visit

3 analyse the consumption patterns of visitors

4 propose recommendations for reinventing a tourism product based on the valuation of local know-how, heritage and creative skills in the form of creative tourism.

This research adopted a case study approach of the municipality of Viana do Castelo. Yin (1984, p.23) defined the case study research method as "an empirical inquiry that investigates a contemporary phenomenon within its real- life context; when the boundaries between phenomenon and context are not clearly evident". Within the case study, a quantitative methodological approach was used based on face-to-face interviews of tourists and same-day-visitors. The non-probability sampling method was used and the convenience sampling technique was chosen. A standard questionnaire was conducted to visitors in the main streets and squares of Viana do Castelo as well as a religious site (Santa Luzia basilica) during April, May and June of 2012 throughout the weekdays and weekends. Other than the Portuguese language, the questionnaire was translated and carried out in three other into languages: English, French and Spanish coinciding with the major generating markets to the Northern Portugal. Altogether, 205 visitors were interviewed. 
The questionnaire design consisted of 27 questions divided into six sections. The first section related to the respondents' place of residence and the period of their visit; Section 2 related to motivations; Section 3 concerned to the sources of information consulted before and during the visit and how they booked the trip; Section 4 inquired about creativity; Section 5 related to the consumption patterns and Section 6 inquired about the respondents' socio-demographic characteristics. The layout used in the questionnaire was adapted from a version used in the ATLAS in the Cultural Tourism Research Project (2007-2009). Statistical Package for the Social Sciences (SPSS) programme version 18.0 was used for the data analysis.

\section{Research results}

\subsection{Visitors' socio-demographic profile}

A majority of visitors are female (57\%) and $43 \%$ male and most are married (57\%). Aggregating the age groups, the main age lies between the ages of 45 and 59, with mean age of 47 years. The majority of visitors $(69 \%)$ hold a higher education degree. Of those, $42 \%$ with a Bachelor's degree and $27 \%$ a Master or Doctoral degree. An additional $19 \%$ completed secondary school, $10 \%$ vocational education and $2 \%$ did not go beyond primary school.

The level of educational qualification of respondents has a major connection to the occupational group. More than $35 \%$ indicate that their current occupational group is the professions, e.g., doctor, lawyer, teacher, etc. A further $25 \%$ describe their current occupation as technical profession and $13 \%$ as director or manager. Other occupations like service and sales personnel (12\%), clerical/administration (12\%), manual and crafts worker (2\%) show a lower percentage. Results are consistent with previous research where cultural tourists are often described as mature, wealthy, highly educated, and female (Urry, 1990 cited in Kim et al., 2007). Visitors are predominantly employed and tend to have professional and technical occupations.

Asked about their current place of residence, over $86 \%$ of respondents were from abroad, followed by visitors from other areas of Portugal (14\%). The top five source markets represent over $60 \%$ of the sample. This list is comprised of France (22\%), Spain $(19 \%)$, Germany $(13.2 \%)$, Brazil $(4.9 \%)$ and Italy (4.4\%). Other countries mentioned include: Netherlands (4\%), Poland (2\%) and Canada (2\%). Some of these are strategic tourism markets for Portugal (MEI, 2011), particularly Spain, France and Germany, three of the four principle tourism markets to Portugal. The other principle market is the UK with little representation in this study $(2.4 \%)$.

Most respondents (52.7\%) travel in groups of two. From those, $46 \%$ travel with their partner followed by friends $(6 \%)$ and other relatives $(2 \%) .23 .9 \%$ of respondents travel in groups of three to four people followed by groups of five or more people (23.4\%).

\subsection{Motivation for the visit}

The main motivation for the visit tends to be 'holiday' and the choice of destination due to its historical architecture (see Figure 2), authentic sights, cultural heritage and 
monuments $(52.7 \%)$. However, only a small portion $(18 \%)$ of visitors considered themselves as being in Viana do Castelo just for cultural purposes. Whereas same-day-visitors choose Viana do Castelo more because of its monumental and cultural heritage, tourists were more motivated by the opportunity to relax. Regardless of the type of motivation for the trip, visitors are keen to visit cultural attractions. In fact, the most commonly visited attractions by all age groups are:

- $\quad$ historic centre (see Figure 3 ) $=91 \%$ of respondents

- $\quad$ religious sites $=58 \%$ of respondents

- $\quad$ monuments $=35 \%$ of respondents

- $\quad$ museums (see Figure 4 ) $=32 \%$ of respondents

- $\quad$ heritage crafts centres $=24 \%$ of respondents

Over $23 \%$ of visitors with a minimum of a Bachelor's degree visited cultural attractions. Whereas tourists are more keen on visiting museums (40\%) and natural sites $(26 \%)$ than same-day-visitors. An important characteristic in culture consumption is visitors' high level of educational attainment (Fernandes and Silva, 2005), which findings of this study confirm.

Figure 2 Historical architecture in Viana do Castelo (see online version for colours)

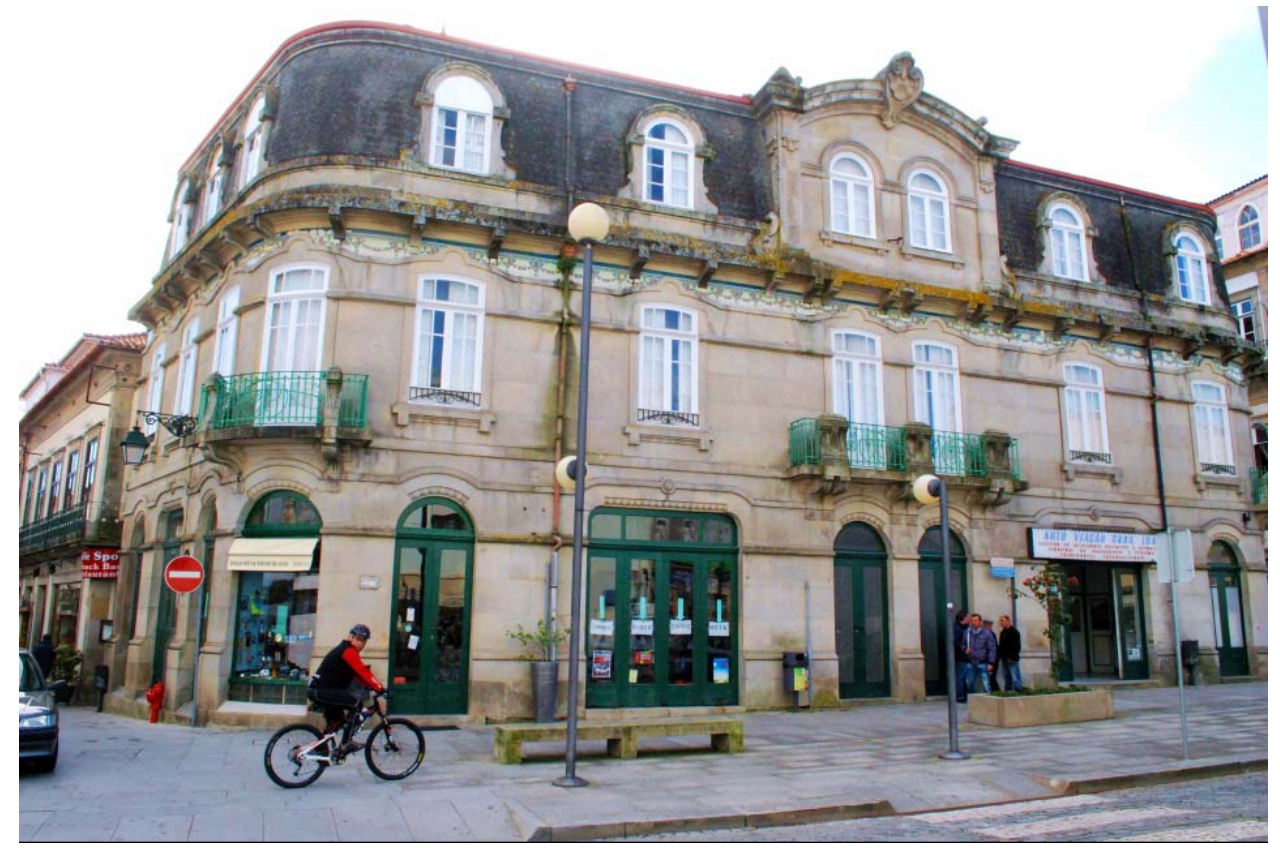

Source: Photograph by Leo Dana 
Figure 3 Historic centre in Viana do Castelo (see online version for colours)

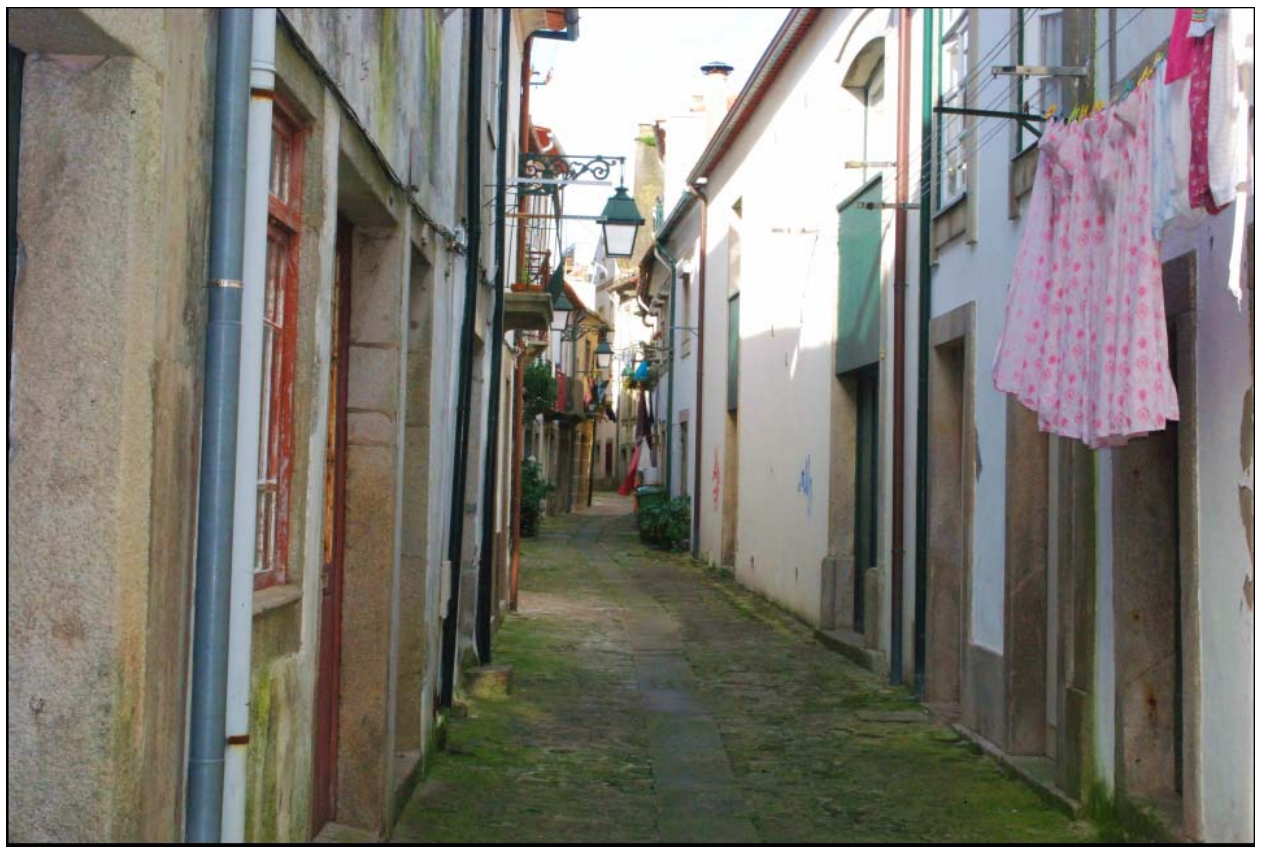

Source: Photograph by Leo Dana

Figure 4 Hospital ship museum in Viana do Castelo (see online version for colours)

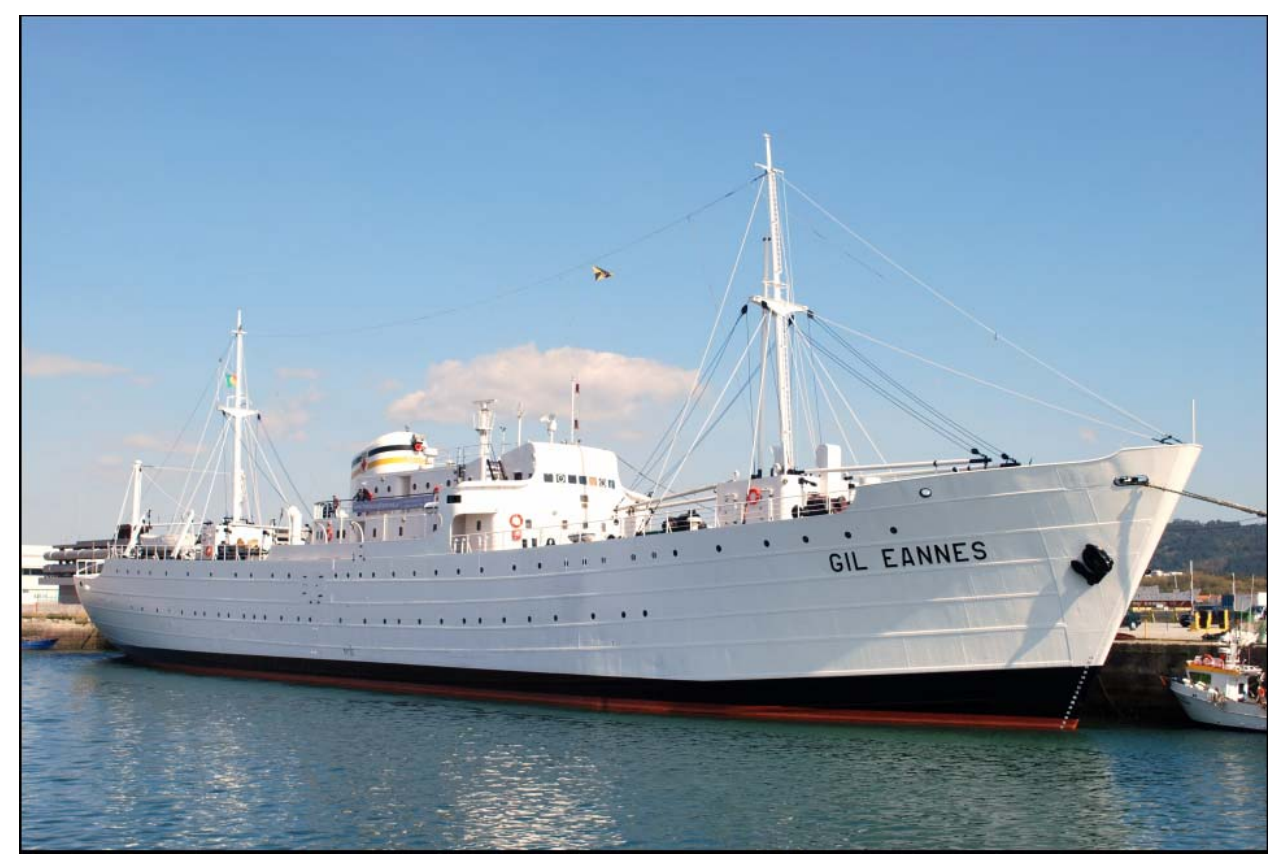

Source: Photograph by Leo Dana 
Richards (1996) argues that participation in heritage tourism is not simply a search for new experiences, but also a search for distinction based on education, occupation and tourism consumption. Also, despite Richards [2001; in Fernandes and Silva, (2005), p.15] having identified museums as the main cultural attraction in Europe, in this research the historic centre and the religious sites are the most visited cultural attractions. This can be explained by the cultural heritage landscape of Viana do Castelo dominated by religious sites, the historic centre and most notably its main square, often referred to as one of the most beautiful squares in all of Europe.

Visitors were asked about which activities they took part in or plan to do so during the visit. The results are cultural routes $(36.6 \%)$ followed by fairs/popular festivals $(21.0 \%)$ and exhibitions (19.5\%). Furthermore, tourists performed or will perform more activities related with walking trails, exhibitions and attending concerts while same-day-visitors performed or will perform more activities related with tasting (wine and food). Respondents consider the activities not only to be important but they also attach a strong involvement/willingness to participate in them. A five-point Likert scale ranging from - not important at all (1) to - very important (5) was used to measure the importance that visitors attached to the activities. Overall, visitors ranked as 'important' $(m d n=4.00)$. The research findings also show that tourists attach more importance to the activities than same-day-visitors. When visitors were asked why they did the activities, $52.0 \%$ answered to increase their knowledge (52.0\%), for entertainment purposes $(42.2 \%)$ and for the experience $(27.9 \%)$. Regarding the degree of involvement/practice that visitors attached to the activities, respondents ranked as strong $(\mathrm{mdn}=4.00)$. The research findings also indicate that visitors were satisfied with the visit to Viana do Castelo $(\mathrm{mdn}=4.00)$.

\subsection{Consumption patterns}

Visitors are mainly independent travellers, possibly a result of the increasing use of technology and the internet for planning their holidays. The majority of visitors $(50.2 \%)$ personally book their travel and accommodation, more so the tourists than same-day-visitors. Those making their own travel arrangements increasingly consult the internet $(48.3 \%)$, followed by travel guides $(37.6 \%)$ and advice of the family and/or friends $(31.2 \%)$. The consultation of internet is higher by tourists while travel guides are more used by same-day-visitors. Television, radio and tour operator brochures play a minor role in terms of sources of information (no reference made to these sources of information). Only $11.2 \%$ of respondents booked an all-inclusive package. Prior research shows that prospective travellers have direct access (online) to a much greater wealth of information provided by tourism organisations, private enterprises and increasingly by other users/consumers (Buhalis and Law, 2008) and the market is taking advantage of these sources. So, an effective online communication strategy should be carefully planned in order to meet costumers' expectations and needs, and consequently boost the tourism demand for the region.

After arriving, the most often used information sources are tourism offices $(42.2 \%)$, travel guides (27.3\%) and local brochures (16.6\%). After arriving, the use of internet becomes even less important, as well as tour operators, newspapers/magazines or television/radio. Guide books are quite popular with foreign tourists upon arrival. The type of accommodation most used by tourists is the four star hotels $(20.4 \%)$, closely followed by youth hostels $(19.5 \%)$, family/friend's house $(15.0 \%)$ and the two star hotels 
(12.4\%). Considering the visitors' occupation group with the choice of accommodation, the majority of respondents classified as professionals chose hotels. $52 \%$ of respondents who chose the youth hostels are professionals from technical areas. As youth hostels are one of the least expensive forms of accommodation and does not offer much comfort or additional services and facilities, it may suggest a shift in visitor's choices and preferences as well as the concept of quality and comfort.

The length of stay among tourists is 1.79 nights, which is consistent with the figure of 1.8 nights provided be INE - National Statistics Institute [INE, (2011), p.405]. The mean number of hours spent by same-day-visitors is 2.09 . The number of nights spent by visitors varied according to the current place of residence. Table 1 gives a short overview of the breakdown. Tourists from France, Germany, Italy and Portugal tend to stay longer, varying between 3 and 8 . For $69.3 \%$ of respondents, it is their first time in Viana do Castelo. It is possible that not being familiar with the destination leads visitors to spend less time on their first visit. This finding is consistent with Fernandes and Silva (2005) suggesting that the relatively high percentage of first time visitors suggest a tendency for more trips to smaller and undiscovered destinations within Europe. The trend seems to include shorter, more frequent gateways and more last minute booking.

Table 1 Length of stay according to visitor' country of origin

\begin{tabular}{lccccc}
\hline \multirow{2}{*}{$\begin{array}{l}\text { Country of } \\
\text { origin }\end{array}$} & \multicolumn{4}{c}{ Number of nights (\%) } & \multirow{2}{*}{ \% total responses } \\
\cline { 2 - 5 } Brazil & $<=2$ & $3-5$ & $6-8$ & $12+$ & \\
\hline France & 80.0 & 20.0 & 0.0 & 0.0 & 4.9 \\
Germany & 86.7 & 0.0 & 8.9 & 4.4 & 22.0 \\
Italy & 77.8 & 7.4 & 14.8 & 0.0 & 13.2 \\
Netherlands & 44.4 & 33.3 & 22.2 & 0.0 & 4.4 \\
Portugal & 100.0 & 0.0 & 0.0 & 0.0 & 3.9 \\
Spain & 72.4 & 17.2 & 10.3 & 0.0 & 14.1 \\
UK & 89.7 & 2.6 & 7.7 & 0.0 & 19.0 \\
\hline
\end{tabular}

The main expense made by tourists was reflected on accommodation $(\mathrm{m}=194.25 €)$, followed by food and beverage $(\mathrm{m}=136.85 €)$, shopping $(\mathrm{m}=104.49 €)$, transport $(\mathrm{m}=83.76 €)$ and entries to attractions $(\mathrm{m}=21.07 €)$. Regarding the expenditure made by same-day-visitors, the transport was the main expense $(\mathrm{m}=66.13 €)$ followed by food and beverage $(\mathrm{m}=40.45 €)$, shopping $(\mathrm{m}=25.00 €)$ and entries to attractions $(\mathrm{m}=5.75 €)$. Visitors travelling with another person (partner or friend) spent the most money per person during the visit, compared to visitors who travel in groups (big or small) who spent less. Admissions to attractions are also relatively low depending on party size. Possible reasons include that groups benefit from discounts. Finally, only $45 \%$ of respondents were satisfied with the visit. Given the general perception that the Portuguese are hospitable hosts, this figure is lower than would perhaps be expected. The low figure may also suggest that the local tourism offer is not properly developed and/or managed to meet the needs of the market. Fernandes and Silva (2005) argue that it may 
be that visitors perceive local attractions and events as not attractive enough. Possibly a lack of creativity in entertainment linked to cultural attractions is turning visitors away. This is also in line with research (Richards and Wilson, 2005) that stresses the need for creative spectacles, spaces and experiences, linking traditional cultural products, services and heritage with creative industries such as entertainment, design and architecture in order to provide great advantages in increasing visitor numbers and length of stay. Creativity and innovation are key for maintaining a place on the cultural tourism map and for attracting repeat visitors due to the increasing competition by tourist destinations.

\subsection{Creative activities}

When looking at the creative activities which visitors usually perform, whether at home or on holiday (within the last 12 months), the most mentioned are photography, culinary/cooking, music and sports. Table 2 illustrates the main creative activities developed by respondents, both at home and on holidays within the last 12 months.

Table 2 Creative activities

\begin{tabular}{ll}
\hline Undertaken at home & Undertaken on holidays \\
\hline $45.9 \%$ photography & $63.9 \%$ photography \\
$43.4 \%$ culinary/cooking & $19.5 \%$ culinary/cooking \\
$29.8 \%$ music & $18.5 \%$ other activity \\
$22.9 \%$ other activity & $16.6 \%$ none of these activities \\
$16.6 \%$ arts & $14.1 \%$ music \\
$15.1 \%$ dance & $14.1 \%$ arts \\
$11.7 \%$ none of these activities & $6.8 \%$ dance \\
$10.2 \%$ crafts & $4.9 \%$ crafts \\
\hline
\end{tabular}

Source: Author

However, not all of these activities can automatically be classified as creative. For example, most people tend to take pictures at one time or another and many visitors consume these activities as part of a wider experience associated with cultural tourism. Nevertheless, results appear to be characterised by a degree of continuity between daily leisure consumption and consumption patterns while on holidays. These results are neither indicative of the degree of active involvement/interactivity that visitors have applied in those activities, nor in the dimension of the active learning which are characteristics of creative tourism. These results can be viewed as an indicator of a consumption pattern somehow related to the enlargement of personal development. Besides the need to gain or maintain social status, currently the need for personal development and inner reflection is revealed on what is argued by Richards and Wilson (2005, p.1220) on the arena of 'becoming' transformed by the tourism experience itself. On the other hand, regarding the 'other activities' undertaken both at home and on holidays respondents mentioned sports suggesting the increasing importance of keeping a healthy lifestyle advocated by the contemporary society. 


\section{Discussion}

When looking at visitor's profile, the main age group lies in ages between 45 and 59 revealing a middle age population, mostly female. Visitors are predominantly employed and tend to have professional and technical occupations.

Tourists originate mainly from France, Spain, Portugal, Germany, Brazil and Italy. Some of these generating markets remain the main producers of tourists abroad, namely Germany and France (UNWTO, 2001), and are strategic tourism markets for Portugal (MEI, 2011).

The main motivation for the visit tends to be 'holiday' and the choice of destination due to its cultural heritage and monuments. However, only a small portion of visitors considered themselves as being in Viana do Castelo just for cultural purposes. Richards (1996) argues that participation in heritage tourism is not simply a search for new experiences, but also a search for distinction based on education, occupation and tourism consumption. In this research the historic centre and the religious sites (rather than museums) were the most visited cultural attractions. This can be explained by the cultural heritage landscape of Viana do Castelo dominated by religious sites, and its outstanding point - the historic centre.

In terms of consumption, visitors occupy their time with cultural routes followed by fairs/popular festivals and handicrafts exhibitions. The reasons to undertaking these activities mainly have to do with increasing knowledge, entertainment and experiences which reflects of findings of other studies, for example, UNWTO (2001), suggesting that product and marketing development will be increasingly targeted, theme-based and broadly oriented to one or a combination of the three e-words: entertainment, excitement and education (the $3 \mathrm{Es}$ ).

Respondents also consider the activities not only to be important and they also attach a strong involvement/ practice to them. It is noteworthy that $46.3 \%$ of respondents travel with their partner/spouse which is reflected in the number of people travelling in group two - as well as in the marital status - married (57.1\%). So the type of activities being organised need to be carefully planned for specific segments of the market.

Visitors are mainly independent travellers, possibly a result of the increasing use of technology and the internet for planning their holidays. There is a high percentage of first time visitors $(69.3 \%)$, choosing the four stars hotel followed by youth hostels as preferred accommodation facilities. These results reflect a sample formed by adults at the top of their career with greater financial ability and the other side, young respondents in the beginning of their career which can not afford high standard hotels.

The main expense made by tourists was reflected on accommodation followed by food and beverage and shopping while the expenditures made by same-day-visitors were reflected on transport followed by food and beverage and shopping. However, the expenses with entries to attractions, for both tourists and same-day-visitors are the lowest which reveal a lack of supply of key 'edutainment' experiences.

The average length of stay reveal that tourists spent an average of 1.79 nights and same-day-visitors spent in average 2.09 hours, which is consistent with the figure of 1.8 nights provided be INE (2011, p.405). 45\% of respondents were satisfied with the visit. Given the general acceptance that the Portuguese are hospitable hosts, this figure is quite lower than would perhaps be expected. The low figure may also suggest that the local tourism offer is not properly developed and/or managed to meet the needs of the market. 
The consultation of the internet followed by travel guides and advices of family/friends are the information sources mostly used by visitors before making the trip, whereas upon arrival the tourism office and the travel guides are the preferred among visitors. Prior research shows that prospective travellers have direct access (online) to a much greater wealth of information provided by tourism organisations, private enterprises and increasingly by other users/consumers (Buhalis and Law, 2008) and the market is taking advantage of these sources. So, online marketing strategy should be carefully planned in order to meet costumers' expectations and needs, and consequently boost the tourism demand for the region.

When looking at the creative activities which visitors usually performed whether at home or on holiday (within the last 12 months) the most mentioned are photography, culinary/cooking, music and sports. However, not all this activities can automatically be classified as creative, for example most people tend to take pictures at one time or another and many visitors consume these activities as part of a wider experience associated with cultural tourism. Nevertheless, results appear to be characterised by a degree of continuity between daily leisure consumption and consumption patterns while on holidays. These results are not indicative of the degree of active involvement/ interactivity that visitors have applied in those activities neither in the dimension of the active learning which are characteristics of creative tourism. On the other hand, these results can be viewed as an indicator of a consumption pattern somehow related to the enlargement of personal development. Besides the need to gain or maintain social status, currently the need for personal development and inner reflection it is revealed on what is argued by Richards and Wilson $(2005, \mathrm{p} .1220)$ on the arena of 'becoming' transformed by the tourism experience itself. Nor, is there evidence of the fact of Viana do Castelo being integrated in the healthy city network has an influence on the decision to visit this destination.

\section{Recommendations and conclusions}

Research findings show that respondents visited Viana do Castelo for holiday purposes looking for local culture and heritage which is reflected in the types of activities undertaken, namely cultural routes, fairs/popular festivals and exhibitions. But while any city that is rich enough can buy itself a Guggenheim museum or a Tate Gallery for visitors to come and see, actively learning cultural and creative skills is best done in the areas in which those skills were developed and where the culture is still alive. Thus, creativity can contribute to reinventing tourism at this traditional cultural tourism destination. Creativity links strongly to issues of identity, distinctiveness and authenticity. Although cultural artefacts may be easy to copy and transport, the essential link between local know-how, cultural landscapes, cultural identity and place is much harder to copy. Creative tourism offers an alternative form of development for areas which may lack high profile cultural resources. It also stimulates regions to think about how existing cultural resources can be used more creatively (Richards, 2011).

Such approach would require establishing service industries knowledge in how to plan and turn Viana do Castelo into a creative destination - the products and processes. Going beyond the basic tourism product and bringing a creative dimension - innovating existing products and creating new ones. Possibly start by focusing on advantage points of the destination, such as its culinary heritage and creative cuisine. Then follow with 
making the farmers markets and emblematic food shops more innovative and transforming traditional food production systems into tourism experiences. Reinforce a networking strategy of regionally-based cultural landscapes to promote cultural touring and cultural routes linked to food products, culinary offer (would require a different approach to culinary identity in Viana do Castelo) and handicrafts. The rejuvenation of traditional skills and crafts could be approached with the introduction of new creative activities to traditional settings of the places in which they are staying. Provide opportunities for engaging experiences for tourists by challenging them to learn new skills while being entertained.

Based on literature (particularly Richards, 2011; Richards and Wilson, 2005, 2007), for developing innovative creative tourism experiences which are distinctive of Viana do Castelo, the following recommendations are made:

1 identify the creative skills which can be harnessed to develop tourist experiences

2 design appropriate creative experiences which are distinctive of the region

3 sharing experience between the partners on appropriate models of experience production

4 market and distribution of creative tourism (website, etc.) and the development of a creative tourism regional network.

\section{References}

ADETURN, Turismo Norte de Portugal (2008) Porto e Norte de Portugal - Estratégia de Marketing Turístico 2007-2015.

Associação de Desenvolvimento Rural Integrado do Lima - ADRIL (2008) Reinventar o Turismo no Minho, ADRIL, Matosinhos.

Associação de Desenvolvimento Rural Integrado do Lima - ADRIL (2011) Vale do Lima - Vale por Si, Divulgação do Vale do Lima e dos seus Recursos Turísticos, ADRIL, Ponte de Lima [online] http://www.center.pt/PT/dossier_adril.pdf (accessed 15 March 2012).

Binkhorst, E. (2006) 'The co-creation tourism experience', ESADE XV International Leisure and Tourism Symposium 'European travelers 2010', Barcelona, Spain, May, pp.1-13.

Buhalis, D. and Law, R. (2008) 'Progress in information technology and tourism management: 20 years on and 10 years after the internet - the state of eTourism research', Tourism Management, Vol. 29, pp.609-623.

Cominelli, F. and Greffe, X. (2012) 'Intangible cultural heritage: safeguarding for creativity', City, Culture and Society, Vol. 3, pp.245-250.

Comissão de Coordenação e Desenvolvimento Regional do Norte - CCDR-N (2008) Plano de Acção para o Desenvolvimento Turístico do Norte de Portugal, CCDR-N, Porto.

DGT (1999) Inventário de recursos turísticos, Sistema de Informação e Gestão de Recursos Turísticos, 2nd ed., Direcção-Geral de Turismo, Lisboa.

European Travel Commission - ETC (2006) Tourism Trends for Europe, European Travel Commission, Brussels [online] http://www.etc-corporate.org/resources/uploads/ ETC_Tourism_Trends_for_Europe_09-2006_ENG.pdf (accessed 6 March 2012).

Fernandes, C. (2011a) 'Cultural planning and creative tourism in an emerging tourist destination', International Journal of Management Cases, Vol. 13, No. 3, pp.629-636.

Fernandes, C. (2011b) Objectives of Tourism Product Development, notes distributed in the theme (Overview of Tourism Product Development: An Introduction), Instituto Politécnico de Viana do Castelo, Escola Superior de Tecnologia e Gestão, 1 February 2011. 
Fernandes, C. and Silva, G. (2005) 'The cultural tourism market in Portugal', International Conference: Recent Developments in Tourism Research, Faro, Portugal, 6-8 October, pp.1-18.

Hosany, S. and Witham, M. (2009) 'Dimensions of cruisers' experiences, satisfaction and intention to recommend', Journal of Travel Research, Vol. 49, No. 3, pp.351-364.

Instituto Nacional de Estatística - INE (2011) Anuário Estatístico da Região Norte 2010, (publication), INE.

Ioannides, D. (2006) 'Chapter 9: re-engineering established products and destinations', Tourism Business Frontiers: Consumers, Products and Industry, pp.77-84, Elsevier Butterworth-Heinemann, Oxford.

Kim, H., Cheng, C.K. and O’Leary, J.T. (2007) 'Understanding participation patterns and trends in tourism cultural attractions', Tourism Management, Vol. 28, No. 5, pp.1366-1371.

Komppula, R. (2001) 'New-product development in tourism companies: case studies on nature-based activity operators', 10th Nordic Tourism Research Conference, Vasa - Finland, 18-20 October, pp.1-20.

Meethan, K. (1998) 'New tourism for old? Policy developments in Cornwall and Devon', Tourism Management, Vol. 19, No. 6, pp.583-593.

Ministério da Economia e da Inovação - MEI (2011) Plano Estratégico Nacional do Turismo: Propostas para revisão no horizonte 2015, Turismo de Portugal, ip, Lisbon [online] http://alturl.com/tbyey (accessed 5 April 2012).

Novelli, M., Schmitz, B. and Spencer, T. (2006) 'Networks, clusters and innovation in tourism: a UK experience', Tourism Management, Vol. 27, No. 6, pp.1141-1152.

Opaschowski, H.W. (2001) Tourismus im 21. Jahrundert das gekaufte paradies, BAT Freizeit-Foschunginstitut, Hamburg.

Piffer, D. (2012) 'Can creativity be measured? An attempt to clarify the notion of creativity and general directions for future research', Thinking Skills and Creativity, Vol. 7, pp.258-264.

Poon, A. (1993) Tourism, Technology and Competitive Strategies, CAB International, Wallingford.

Richards, G. (1996) 'Production and consumption of European cultural tourism', Annals of Tourism Research, Vol. 23, No. 2, pp.261-283.

Richards, G. (2011) 'Creativity and tourism: the state of the art', Annals of Tourism Research, Vol. 38, No. 4, pp.1225-1253.

Richards, G. and Raymond, C. (2000) 'Creative tourism', ATLAS News, Vol. 23, pp.16-20.

Richards, G. and Wilson, J. (2005) 'Developing creativity in tourist experiences: a solution to the serial reproduction of culture', Tourism Management, Vol. 27, pp.1209-1223.

Richards, G. and Wilson, J. (2007) Tourism, Creativity and Development, Routledge, London.

Rogerson, C. (2006) 'Creative industries and urban tourism: South African perspectives', Urban Forum, Vol. 17, No. 2, pp.149-166.

Sampaio, F. (1991) O Produto Turístico do Alto Minho. Viana do Castelo: Região de Turismo do Alto Minho, Costa Verde, Portugal.

Sampaio, F. (1994) O Produto Turístico do Alto Minho II. Viana do Castelo: Região de Turismo do Alto Minho, Costa Verde, Portugal.

Sepe, M. and Di Trapani, G. (2010) 'Cultural tourism and creative regeneration: two case studies', International Journal of Culture, Tourism and Hospitality Research, Vol. 4, No. 3, pp.214-227.

Stamboulis, Y. and Skayannis, P. (2003) 'Innovation strategies and technology for experience-based tourism', Tourism Management, Vol. 24, pp.35-43.

UNESCO (2006) Towards Sustainable Strategies for Creative Tourism, Creative Cities Network, UNESCO, Santa Fe, New Mexico, USA [online]

http://unesdoc.unesco.org/images/0015/001598/159811e.pdf (accessed 6 March 2012) 
United Nations Conference on Trade and Development - UNCTAD (2010) Creative Economy Report 2010: A Feasible Development Option, UNCTAD, Geneva.

UNWTO - World Tourism Organization (2001) Tourism 2020 Vision Volume 7: Global Forecasts and Profiles of Market Segments, World Tourism Organization, Madrid.

Yin, R. (1984) Case Study Research: Design and Methods, Sage Publications, Newbury Park, CA. 